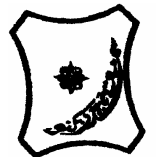

Bayero Journal of Pure and Applied Sciences, 4(1): 48 - 51

Received: August, 2010

Accepted: March, 2011

ISSN 2006 - 6996

\title{
PERFORMANCE OF SOME DURUM WHEAT VARIETIES AT KADAWA, KANO STATE OF NIGERIA
}

\author{
Falaki $^{1}$, A. M. and I. B. Mohammed ${ }^{2} *$ \\ ${ }^{1}$ Ahmadu Bello University, Zaria, Kaduna State, Nigeria. \\ ${ }^{2}$ Department of Agronomy, Faculty of Agriculture, Bayero University, Kano State, Nigeria. \\ *Corresponding Author: ibabamohd@yahoo.co.uk
}

\begin{abstract}
$A$ two-year trial was conducted during the 2001/02 and 2002/03 dry seasons at Kadawa (lat. $11^{0}$ $39^{\prime} \mathrm{N}$, long. $08^{\circ} 27^{\prime} \mathrm{E}$ and $500 \mathrm{~m}$ above sea level) to evaluate the performance of twelve durum wheat varieties. The varieties were laid out in Randomized Complete Block Design with three replications. The results revealed that plant height of wheat was influenced by variety in 2002/03 season only while number of tillers/plant, number of grains/spike, grain weight/spike/1000-grain weight and grain yield were significantly affected in both seasons. Variety Tody- 6 and Anser-8 outyielded the other varieties in 2001/02 and 2002/03, respectively. Thus, the two varieties could be selected for higher yields of durum wheat in the study area.
\end{abstract}

Keywords: Durum wheat, Grain yield, Kadawa, Sudan savanna, Nigeria.

\section{INTRODUCTION}

Wheat is a crop of major interest in Nigeria as it is the main component of bread and other wheat-based products such as cakes, biscuits, macaroni, spaghetti, pasta, etc. In Nigeria, because of high temperature and humidity, the local climatic conditions have not been favourable for optimum growth and yield of wheat. Accordingly, the climatic potential for wheat production generally decreases equator-wards due to consistently high temperature and humidity (Oche, 1998). Thus, production is presently restricted to areas between latitudes $10-14^{\circ} \mathrm{N}$ (covering the Sudan and Sahel savanna zones), during the cold harmattan period between the months of November and February, under irrigation (Abbas, 1988).

According to Anonymous (2006) the increasing consumption and demand for wheat in Nigeria was largely due to increase and expansion in bread and pasta industries, and for the manufacture of crackers, noodles etc. Presently, domestic wheat demand in the country is far more than local production; consequently $90-95 \%$ of wheat consumed is imported from the United States of America. For example, the country imported 4.3 million tons of wheat in 2007 as against 3.8 million tons in 2006.

Increasing wheat production in Nigeria requires prior investigation of the crop's requirements. In places with relatively low technology as obtainable in developing countries like Nigeria, a naturally favourable environment is paramount for optimum production. Even where all production inputs could be met, the choice of appropriate genotypes is imperative. Peterson (1965) had indicated that wheat varieties with broad adaptation to climatic and soil conditions should be adopted for high productivity. Early wheat variety screening trials at Kadawa, northern Nigeria by Fisher and Maurer (1978) and Orakwue et al, (1991) indicated that varieties with superior drought tolerance gave higher yields more especially under sub-optimal growing conditions. A more recent study by Miko et al, (2006) at same location also, found differential response of two Mexican wheat varieties to the growing conditions, which was attributed to their varied reactions to applied fertilizers and adaptability to environment.

Therefore, the present investigation was aimed at identifying promising durum wheat varieties introduced from CIMMYT, Mexico, with superior adaptation to the local growing conditions in the Sudan savanna ecological zone, Nigeria.

\section{MATERIALS AND METHODS}

Two irrigated field trials were conducted at Kadawa (lat. $11^{\circ} 39^{\prime} \mathrm{N}$, long. $08^{\circ} 27^{\prime} \mathrm{E}$ and $500 \mathrm{~m}$ above sea level) in Kano State situated in the Sudan savanna ecological zone of Nigeria, during 2001/02 and 2002/03 dry seasons. The soils of the experimental site were sandy loam.

The varieties consisted of twelve durum wheat varieties laid out in randomized complete block design with three replications. Gross plot size was 5 $\mathrm{m} \times 5 \mathrm{~m}$ while net plot was $3 \mathrm{~m} \times 5 \mathrm{~m}$. Seed rate of $100 \mathrm{~kg} / \mathrm{ha}$ was used and seeds were sown by hand drilling at a row spacing of $20 \mathrm{~cm}$. Sowing was done by mid-December in all the seasons. At planting, the plots were given minimum of $50 \mathrm{~kg} \mathrm{~N}, 50 \mathrm{~kg} \mathrm{P}_{2} \mathrm{O}_{5}$ and $50 \mathrm{~kg} \mathrm{~K}_{2} \mathrm{O} / \mathrm{ha}$ in the form of NPK 15: 15: 15. At four weeks after planting top dress of $50 \mathrm{~kg} \mathrm{~N} / \mathrm{ha}$ was applied in the form of Urea $(46 \% \mathrm{~N})$. Weeds were removed manually by regular hoe weeding. Irrigation was by gravity and given at 10 days interval from sowing until three weeks to harvest when irrigation was stopped to allow for proper and faster ripening. In both seasons, crops were ready for harvesting in April. Motorized thresher was used for threshing the manually harvested crop. 
Data collected included plant height at harvest, number of tillers/plant, number of spikelets/spike, length of spike, number of grains/spike, grain weight/spike, 1000-grain weight and grain yield $(\mathrm{kg} / \mathrm{ha})$. The net plots were used for yield data while the discard was used for the growth characters examined. Data collected were subjected to analysis of variance and treatment effects were compared using Duncun Multiple Range Test (Duncan, 1955).

\section{RESULTS}

Analysis of soils in 2002/03 (A. O.A.C. 1980) showed that the soils were slightly acidic ( $\mathrm{pH} 5.9$ in $\mathrm{CaCl}_{2}$ ), fairly low in organic carbon $(4.3 \mathrm{~g} / \mathrm{kg})$, medium in phosphorus $(19.7 \mathrm{mg} / \mathrm{kg}$ ) and fairly low in residual nitrogen $(0.24 \mathrm{~g} / \mathrm{kg})$. The maximum and minimum temperatures were $38.2^{\circ} \mathrm{C}$ and $12.4^{\circ} \mathrm{C}$, respectively, while the relative humidity was between 8 and 78\% (Appendix 1).

Plant height of the wheat varieties was only significantly different in 2002/03 season when Spot-2 and Alter-84 recorded shorter plants compared with the other varieties (Table 1 ). In both seasons Tody- 6 produced significantly higher number of tillers/plant compared with the other varieties while Minimus-2 had the least values (Table 1). Similarly, across the two seasons, Tody- 6 recorded the highest number of spikelets/spike which was statistically similar with Mexicali-75, Silver-15, Plata18 and SN-Turk in 2001/02. In 2002/03 season however, Tody- 6 recorded similar number of spikelets/spike with the other varieties except Betriq-4 and Anser-8. On the other hand, in both seasons Betriq-4 produced the lowest number of spikelets/spike.

Table 2 revealed that in 2001/02 Silver-15 and Tody- 6 had the longest spikes while in 2002/03 Silver-15 was superior to the other varieties. However, in both seasons Betriq-4 produced the shortest spikes. The number of grains/spike of the wheat varieties differed significantly in 2002/2003 season only, whereas Minimus2 produced statistically lower values compared with the other varieties except Silver-15, Nasser-5 and Anser-8 which have intermediate number of grains/spike. In both seasons Mexicali-75 and Tody- 6 had significantly similar and higher grain weight/spike compared with the other varieties, although the values were statistically at par with few others (Table 2). Also, in both seasons Minimus2 recorded the lowest grain weight/spike.

The effect of variety on 1000-grain weight was significant in 2002/2003 season (Table 3). Variety $\mathrm{SN}$-Turk was superior to the other variety though at par with most others while Minimus-2 had the least 1000grain weight/spike. In 2001/02 season Tody-6 had significantly higher grain yield compared with Minimus- 2 while the other varieties had similar and intermediate 1000-grain weight/spike (Table 3). However, in 2002/03 Anser-8 though at par with many others, produced the highest grain yield while Silver-15 produced the lowest yield.

\section{DISCUSSION}

The results showed that Tody- 6 and Anser- 8 had superior grain yields than the other wheat varieties. Similar varietal differences in the performance of wheat have been reported by Abubakar et al, (2000) and Olugbemi, (1984), attributing such response to varied interaction between the genotypes and environment. In a related development however, Ferns et al, (1975) noted that superior adaptation to local soil and climatic conditions as well as resistance to diseases were the main support for higher grain yield of wheat. The non significant differences in plant height, number of grains/spike and 1000 -grain weight among the varieties in 2001/02 as well as the inconsistent pattern of response in other yield characters across the two seasons, could also be due to changes in climatic variables, particularly temperature in the two seasons (Anonymous, 1979).

The result of the present study is important particularly now that efforts to boost local production of wheat are needed to stem Nigeria's rising import bills for the crop which is $16 \mathrm{bn}$ annually (Anonymous, 2008). There is however, the need for further investigations to determine the fertilizer requirements of the promising varieties before extending same to farmers for adoption.

Conclusion: From the results of the two years study, it could be concluded that Tody- 6 and Anser- 8 have the potentials to perform higher than the other wheat varieties tested under the prevailing growing conditions of the Sudan savanna zone of Nigeria.

Table 1. Plant height and number of tillers/plant and number of spikelets/spike of Durum wheat varieties in 2001/02 and 2002/03 dry season at Kadawa.

\begin{tabular}{|c|c|c|c|c|c|c|}
\hline \multirow[t]{2}{*}{ Treatments } & \multicolumn{2}{|c|}{ Plant height (cm) } & \multicolumn{2}{|c|}{ Number of tillers/plant } & \multicolumn{2}{|c|}{ Number of spikelets/spike } \\
\hline & $2001 / 02$ & $2002 / 03$ & & & & \\
\hline \multicolumn{7}{|l|}{ Variety } \\
\hline Silver-12 & 67.7 & $67.0^{\mathrm{ab}}$ & $9.4^{\mathrm{abc}}$ & $9.9^{\mathrm{abcd}}$ & $13.7^{\text {cd }}$ & $14.7^{\mathrm{abc}}$ \\
\hline Betriq-4 & 62.0 & $65.0^{\mathrm{ab}}$ & $10.1^{\mathrm{abc}}$ & $11.4^{\mathrm{ab}}$ & $12.3^{\mathrm{d}}$ & $11.3^{\mathrm{c}}$ \\
\hline Mexicali-75 & 66.3 & $69.7^{\mathrm{ab}}$ & $9.9^{\mathrm{abc}}$ & $10.1^{a-d}$ & $15.7^{\mathrm{abc}}$ & $15.7^{\mathrm{ab}}$ \\
\hline Minimus-2 & 62.0 & $64.0^{\mathrm{ab}}$ & $7.7^{\mathrm{c}}$ & $8.0^{\mathrm{d}}$ & $13.7^{c d}$ & $14.3^{\mathrm{abc}}$ \\
\hline Silver-15 & 73.0 & $77.0^{\mathrm{a}}$ & $10.9^{\mathrm{ab}}$ & $10.9^{\mathrm{abc}}$ & $15.7^{\mathrm{abc}}$ & $15.3^{\mathrm{ab}}$ \\
\hline Plata-18 & 68.0 & $69.3^{\mathrm{ab}}$ & $9.2^{\mathrm{abc}}$ & $10.7^{\mathrm{abc}}$ & $15.7^{\mathrm{abc}}$ & $13.7^{\mathrm{abc}}$ \\
\hline Nasser-5 & 66.7 & $74.0^{\mathrm{ab}}$ & $8.1^{\mathrm{c}}$ & $8.9^{\mathrm{cd}}$ & $14.3^{\mathrm{bcd}}$ & $15.0^{\mathrm{ab}}$ \\
\hline Anser-8 & 66.0 & $67.0^{\mathrm{ab}}$ & $8.6^{\mathrm{bc}}$ & $9.6^{\mathrm{bcd}}$ & $13.3^{\text {cd }}$ & $12.3^{\mathrm{bc}}$ \\
\hline Spot-2 & 60.7 & $60.3^{b}$ & $9.9^{\mathrm{abc}}$ & $10.4^{\mathrm{abc}}$ & $14.3^{\mathrm{bcd}}$ & $14.0^{\mathrm{abc}}$ \\
\hline Tody-6 & 68.7 & $68.3^{\mathrm{ab}}$ & $11.5^{\mathrm{a}}$ & $12.1^{\mathrm{a}}$ & $17.3^{\mathrm{a}}$ & $16.3^{\mathrm{a}}$ \\
\hline SN-Turk & 60.3 & $62.0^{a b}$ & $109^{\mathrm{ab}}$ & $11.9^{\mathrm{ab}}$ & $16.7^{\mathrm{ab}}$ & $15.7^{\mathrm{ab}}$ \\
\hline Alter-84 & 64.3 & $60.7^{b}$ & $11.4^{\mathrm{a}}$ & $10.4^{\mathrm{abc}}$ & $14.7^{\mathrm{bcd}}$ & $13.3^{\mathrm{abc}}$ \\
\hline LSD & 20.6 & 13.6 & 2.1 & 2.11 & 2.21 & 3.08 \\
\hline
\end{tabular}

Means followed by the same letter (s) within a column are statistically similar at $5 \%$ level of probability using DMRT. 
Table 2. Length of spike, number of grains/spike and grain weight/spike of Durum wheat varieties in 2001/02 and 2002/03 dry season at Kadawa.

\begin{tabular}{|c|c|c|c|c|c|c|}
\hline \multirow[t]{2}{*}{ Treatments } & \multicolumn{2}{|c|}{ Length of spike } & \multicolumn{2}{|c|}{ Number of grain/spike } & \multicolumn{2}{|c|}{ Grain weight/spike } \\
\hline & $2001 / 02$ & $2002 / 03$ & $2001 / 02$ & $2002 / 03$ & $2001 / 02$ & $2002 / 03$ \\
\hline \multicolumn{7}{|l|}{ Variety } \\
\hline Silver-12 & $5.4^{\mathrm{bcd}}$ & $5.53^{\mathrm{bcd}}$ & 35.0 & $35.0^{\mathrm{ab}}$ & $1.77^{\mathrm{bc}}$ & $1.80^{\mathrm{bc}}$ \\
\hline Betriq-4 & $5.2^{\mathrm{cd}}$ & $5.17^{\mathrm{cd}}$ & 39.0 & $38.0^{\mathrm{a}}$ & $1.77^{\mathrm{bc}}$ & $2.03^{\mathrm{abc}}$ \\
\hline Mexicali-75 & $6.2^{\mathrm{abc}}$ & $5.83^{\mathrm{abcd}}$ & 37.3 & $38.0^{a}$ & $2.97^{a}$ & $2.80^{\mathrm{a}}$ \\
\hline Minimus-2 & $5.0^{\mathrm{d}}$ & $5.20^{\mathrm{cd}}$ & 28.7 & $28.0^{b}$ & $1.27^{\mathrm{c}}$ & $1.27^{\mathrm{c}}$ \\
\hline Silver-15 & $6.6^{\mathrm{a}}$ & $7.33^{a}$ & 39.7 & $39.3^{a}$ & $2.73^{\mathrm{ab}}$ & $2.77^{\mathrm{ab}}$ \\
\hline Plata-18 & $6.5^{\mathrm{ab}}$ & $6.87^{\mathrm{ab}}$ & 38.7 & $37.7^{a}$ & $2.43^{\mathrm{ab}}$ & $2.47^{\mathrm{ab}}$ \\
\hline Nasser-5 & $4.6^{d}$ & $4.57^{d}$ & 35.3 & $35.3^{\mathrm{ab}}$ & $2.63^{\mathrm{ab}}$ & $2.33^{\mathrm{ab}}$ \\
\hline Anser-8 & $6.4^{\mathrm{ab}}$ & $6.37^{\mathrm{abc}}$ & 32.3 & $33.3^{\mathrm{ab}}$ & $2.30^{\mathrm{ab}}$ & $2.13^{\mathrm{abc}}$ \\
\hline Spot-2 & $5.8^{\mathrm{abcd}}$ & $5.77^{\mathrm{abcd}}$ & 37.3 & $38.7^{a}$ & $2.07^{\mathrm{abc}}$ & $2.03^{\mathrm{abc}}$ \\
\hline Tody-6 & $6.6^{\mathrm{a}}$ & $6.53^{\mathrm{bcd}}$ & 37.0 & $38.3^{a}$ & $2.87^{\mathrm{a}}$ & $2.90^{\mathrm{a}}$ \\
\hline SN-Turk & $6.3^{\mathrm{abc}}$ & $6.70^{\mathrm{abc}}$ & 39.3 & $40.3^{a}$ & $2.63^{\mathrm{ab}}$ & $2.57^{\mathrm{ab}}$ \\
\hline Alter-84 & $5.7^{\mathrm{abcd}}$ & $5.63^{\mathrm{bcd}}$ & 37.7 & $36.7^{a}$ & $2.07^{\mathrm{abc}}$ & $2.53^{\mathrm{ab}}$ \\
\hline LSD & 1.03 & 1.44 & 10.2 & 7.74 & 0.89 & 0.86 \\
\hline
\end{tabular}

Means followed by the same letter (s) within a column are statistically similar at $5 \%$ level of probability using DMRT.

Table 3. 1000-grain weight and grain yield of Durum wheat varieties in 2001/02 and 2002/03 dry season at Kadawa.

\begin{tabular}{|c|c|c|c|c|}
\hline \multirow[t]{2}{*}{ Treatments } & \multicolumn{2}{|c|}{ 1000-grain weight (g) } & \multicolumn{2}{|c|}{ Yield kg/ha } \\
\hline & $2001 / 02$ & $2002 / 03$ & $2001 / 02$ & $2002 / 03$ \\
\hline \multicolumn{5}{|l|}{ Variety } \\
\hline $\overrightarrow{\text { Silver-12 }}$ & 11.7 & $11.4^{\mathrm{bcd}}$ & $2644^{\mathrm{ab}}$ & $2311^{\mathrm{cd}}$ \\
\hline Betriq-4 & 14.4 & $14.6^{\mathrm{abc}}$ & $3133^{a b}$ & $2622^{a-d}$ \\
\hline Mexicali-75 & 14.5 & $15.0^{\mathrm{ab}}$ & $3133^{a b}$ & $2666^{a-d}$ \\
\hline Minimus-2 & 10.5 & $10.1^{\mathrm{d}}$ & $1911^{\mathrm{b}}$ & $2911^{a b c}$ \\
\hline Silver-15 & 13.2 & $12.9^{a-d}$ & $3177^{\mathrm{ab}}$ & $2488^{b c d}$ \\
\hline Plata-18 & 13.7 & $11.4^{\mathrm{bcd}}$ & $2977^{\mathrm{ab}}$ & $1755^{d}$ \\
\hline Nasser-5 & 10.8 & $12.0^{\mathrm{a}-\mathrm{d}}$ & $2555^{a b}$ & $2622^{a-d}$ \\
\hline Anser-8 & 11.3 & $10.9^{\text {cd }}$ & $2533^{a b}$ & $3622^{a}$ \\
\hline Spot-2 & 11.1 & $11.4^{\mathrm{bcd}}$ & $2488^{a b}$ & $3433^{\mathrm{ab}}$ \\
\hline Tody-6 & 13.6 & $14.4^{\mathrm{abc}}$ & $3422^{a}$ & $3000^{a b c}$ \\
\hline SN-Turk & 13.3 & $15.5^{\mathrm{a}}$ & $3200^{a b}$ & $3333^{\mathrm{ab}}$ \\
\hline Alter-84 & 15.3 & $12.1^{\mathrm{a}-\mathrm{d}}$ & $2967^{a b}$ & $3377^{a b}$ \\
\hline LSD & 4.83 & 3.38 & 1115 & 871 \\
\hline
\end{tabular}

Means within each column followed by the same letter are not significantly different at 5\% as determined by Duncan's Multiple Range Test.

Appendix 1.Soil analysis and some Metrological information of the experimental area

\begin{tabular}{lll}
\hline Soil $\mathrm{pH}$ in Cacl2 & & 5.9 \\
Organic carbon & & $4.3 \mathrm{~g} / \mathrm{kg}$ \\
Phosphorus & & $19.7 \mathrm{mg} / \mathrm{kg}$ \\
Residual nitrogen & & $0.24 \mathrm{~g} / \mathrm{kg}$ \\
\hline Metrological Data & Maximum & Minimum \\
\hline Temperature & $38.2^{0} \mathrm{C}$ & $12.4^{0} \mathrm{C}$ \\
Relative humidity & $8 \%$ & $78 \%$
\end{tabular}

\section{REFERENCES}

Abbas, $\quad$ M. $1988 . \quad$ First $\quad$ CIMMYT (Mexico)/NAFPP/AERLS/NSS Joint One Week Intensive Training Course in International Wheat Production. Jan. $18^{\text {th }}-23^{\text {rd }}, 1988$. pp 13.

Abubakar, I.U., Miko S., Falaki, A. M. and Valencia J. A. 2000. Response of Irrigated wheat
(Triticum aestivum L.) to planting methods and nitrogen level in the northern Guinea savanna of Nigeria. Journal of Agriculture and Environment. 1(2): 111-118.

Anonymous 1979. Report on wheat production and marketing in Nigeria. Shina Commercial Press, Zaria. pp 97. 
Anonymous (2006). Grain Report. USDA Foreign Agricultural Service, Nigeria Grain and Feed Annual 2006.

http://www.fas.usda.gov/gainfiles/200605/146187618 .pdf

Anonymous 2008. Nigeria spends N6bn annually on wheat importation. http://www.punchng.com/Articl.aspx?theartic $=$ Art200803100125415

A. O. A. C. 1980 . Association of Official Analytical Chemist. Official Methods of Analysis $1313^{\text {th }}$ ed. Washington D.C.

Duncan, D.B. 1955. Multiple range and Multiple "F" test. Biometric 11: 1-42

Ferns, G. K., Fitzsimmous, R. W., Martin, R. H., Simmonds, D. H. and Wrigley, C. N. (1975). Australian Wheat Variety Identification according to Growth, Heading and Grain Characteristics. CSIRO. pp 126.

Fisher, R. A. and R. Mauner 1978. Drought resistance in wheat cultivars. Grain yield response. Australian Journal of Agricultural Research. 29:897-912.

Miko, S., Falaki, A. M., Abubakar, I.U. and Valencia, J. A. 2006. Response of two wheat (Triticum estivum L.) varieties to different rates of applied NPK fertilizer. Biological and Environmental Sciences Journal for the Tropics 3(4):18-22.

Oche, C. Y. 1998. Agro-climatic Zonation for Wheat Production in savanna Region of Nigeria. Singapore Journal of Tropical Geography. Vol. 19, No. 1, 39-50.

Olugbemi, L.B. 1984. Effect of varieties and fertilizer on yield of irrigated wheat in northern Nigeria. Samaru Journal of Agricultural Research. 2 (1 and 2): 25-33.

Orakwe, F. C., Olugbemi, L. B., Olarewaju, J. A. and Aremu, J. A. 1991. Development of wheat germplasm with moisture tolerance in Nigeria. Proceeding of the $11^{\text {th }}$ National Irrigation and Drainage Seminar. 93-99.

Peterson, R. F. 1965. Wheat Botany, Cultivation and Utilization. Interscience Publishers inc NY pp 422. 